\title{
Yeats's Evolution from The Shadowy Waters to At the Hawk's Well
}

Ángel Pérez Vázquez

I. B. núm. 4, Elche

\begin{abstract}
My purpose in this essay is to study the evolution of Yeats's dramatic style from The Shadowy Waters to At the Hawk's Well. I will be considering changes in dramatic technique as well as in Yeats's world-view. As a middle point between these two plays, I have also chosen to study The Hour-Glass (1914), the last play that Yeats wrote before adopting the Noh form in At the Hawk's Well (1917), and which, for Francisco Javier Torres Ribelles "can be considered the expression of Yeats's own symbolist theories" (26). The version of The Shadowy Waters that I will be referring to is the final acting version of 1911 . Occasional references to other works by Yeats, both dramatic and poetic, will nevertheless be included.
\end{abstract}

There is a feature which The Shadowy Waters and The Hour-Glass share, and which At the Hawk's Well does not. I am referring to the combination of prose and verse. The changes from prose to verse and vice versa seem to signal, both in The Shadowy Waters and in The Hour-Glass, moves into different levels of reality. There is a difference, though: In The Shadowy Waters, the changes from prose to verse correspond to changing speakersobviously no such changes occur in the 1906 version, which is all verse and "must be considered as a poem only" (Yeats, Collected Poems 473) - whereas in The Hour-Glass the changes occur within the speech of given characters, namely the Wise Man and the pupils. In The Shadowy Waters the sailors speak in prose, whereas Forgael, Dectora and Aibric speak in verse. Two different worlds are apparent in this play: on the one hand, the world of common reality, which is embodied in the sailors, and on the other hand the world of Forgael, Dectora and Aibric, which represents the sublime, or "superior" reality. Yeats seems to be technically pointing out the difference between the two by making the sailors speak prose, and the other characters verse. The changes from prose to verse and vice versa in The Shadowy Waters, then, seem to mark, not changes between levels of reality proper, but changes between two worlds, embodied in two different sets of 
characters who symbolize two levels of reality. If we were to speak of the different levels of reality proper which effectively operate in this play, we would have to refer to (a) Forgael in his sleep, (b) Forgael awake, (c) the other characters enchanted by Forgael, (d) the other characters not enchanted by Forgael, (e) the actual reality, shared by the audience, of the play being performed on stage. Obviously, what the changes between prose and verse mark is not the changes between these five levels. Perhaps the best way to put it would be to say that Yeats's technique in this respect consists of employing these changes between prose and verse in order to help the audience to identify two symbolized worlds.

Yeats's procedure is different in The Hour-Glass. In this play, as we said, the changes occur within the speech of the Wise Man, who actually moves into a different level of reality when the change takes place. Perhaps the word "conscience" is more appropriate here than "reality," as what, for instance, the Wise Man undergoes when shifting from prose to verse is truly a change.in his conscience, by virtue of which he adopts the world of the Fool, and rejects his own earlier rational, materialistic world, with the paradoxical outcome that the roles of fool and wise man are thus reversed in the system of values which Yeats exhibits in this play. The result is that the real wise man is the one who is endowed with the power of apprehending the deeper reality of the supernatural and the world of dreams, i.e. the Fool. The Wise Man's change from prose to verse also marks, however, a move into another level of reality, as we said before, since the shift to verse coincides with the presence or the influence of the supernatural, symbolized by the Angel, which in this play appears surrounded by a dream-like atmosphere. All this is convincingly explained and related to questions of subject-matter by Francisco Javier Torres Ribelles (30-31), whose terminology differs from mine in that he uses the expressions "opposing characters" where I have used "worlds symbolized by different characters," and "worlds" where I have used "levels of reality" and "conscience":

[In The Hour-Glass] [p]rose and poetry are not forms of expression used by opposing characters [as they are in The Shadowy Waters]. Instead, Yeats uses the devices characteristic of each of them to bring forth two different worlds, "two living countries, one visible and one invisible" ... Their collision has a parallel in the Wise Man's inner fight: between the domain of materialistic perception, ruled by the laws of scientific rationalism, and the realm of intangibility, that can be reached when senses are endowed with their total power, namely, when they are turned into passions. While the Wise Man remains within the limits imposed by logic, he makes use of prose, which in his case is characterized by a down-to-earth quality and a rhetorical tone. Also distinguished by his recourse to complex subordinations, his speech often turns into mediaeval Latin, a mutation which is made absurd by the irony of the play, investing the Wise Man's expression with an abstract pedanticism. On the standard stage the Latin in the text has a useless function as a vehicle for conveying denotative meaning, and in regard to connotations it is an important factor for the audience to equate science and lack of comprehension.

I associate the Wise Man with one of those "bald heads forgetful of their sins" ridiculed by Yeats in his poem "The Scholars." The Wise Man starts to change his intellectual 
outlook, though, when, at the beginning of the play (302-303 in the edition we shall be quoting from), he first changes from prose to verse. After a speech in prose, where we find him actively engaged in discrediting belief in the supernatural world and asserting his faith in rational thought, the Wise Man changes from prose to verse:

Were it but true, 'twould alter everything

Until the stream of the world had changed its course.

And that and all our thoughts had run

Into some cloudy thunderous spring

They dream to be its source-

Aye, to some frenzy of the mind;

And all that we have done would be undone,

Our speculation but as the wind.

[A pause.

I have dreamed it twice.

The Wise Man has fallen into a sort of a rapture and begins to come under the influence of the supernatural, which he can only apprehend in his dreams. He is contemplating the consequences of a possible collapse of the rational world. The First Pupil even notes that "something has troubled him." Then the Wise Man continues:

Twice have I dreamed it in a morning dream,

Now nothing serves my pupils but to come

With a like thought. Reason is growing dim;

A moment more and Frenzy will beat his drum

And laugh aloud and scream;

And I must dance in the dream.

No, no, but it is like a hawk, a hawk of the air, It has swooped down-and this swoop makes the third-

And what can I, but tremble like a bird?

In this dreamy rapture the Wise Man foresees the loss of faith in Reason which he is about to undergo. After this moment of confusion the Wise Man shifts back to prose, only to return to verse when he is completely under the influence of the Angel. The pupils also change from prose to verse, and in their case there is an element of irony in that they seem to be imitating their master's, for them, surprising new style (one of them even remarks on this) just as they have imitated his quaint Latinisms before, from which they violently move into the verse they hear in the master's speech. They still use verse, though, to remind the Wise Man of all his rationalistic teachings, just like they have been using his Latin just before. They are indirectly, through the master's influence, also under the power of the Angel, though they deny it as they cannot grasp it in the rational terms long-imbued in them by the Wise Man. They do not know or understand that their conscience is starting to be manipulated in the same way, Yeats seems to be suggesting, as it has always been. They seem to be repeating like parrots, imitating form. It is in this uncritical attitude that the element of irony I mentioned can be seen. 
The hawk here seems to be related to the Angel, who will appear soon afterwards. In fact, after the Wise Man has talked to the Angel, who has shaken his faith in Reason and exhorted him to find a believer before the sand runs through the hour-glass, we find the pupils reminding him of his earlier beliefs, and encouraging him to preserve them. The Wise Man says (314):

Something incredible has happened-someone has come Suddenly like a grey hawk out of the air, And all that I declared untrue is true.

Yeats called the hawk "one of the natural symbols of subjectivity" (Saul 48; Donoghue 160). This is appropriate here, if we think of subjectivity as a means of apprehending the supernatural, or as the human quality which belief in the supernatural may arise from. Yeats also said that the hawk-woman in At the Hawk's Well represented "intellect" (Saul 49). Ellmann (216) says it symbolizes "logic and abstract thought." I will not get into a discussion on whether the hawk represents subjectivity or intellect or logic and abstract thought (for me, anyway, it is appropriate to speak of intellect-or logic and abstract thought-in At the Hawk's Well, and of subjectivity in The Hour-Glass and "The Hawk"). I would argue, rather, that what is really important here is that, whether it be one or the other of these two notions, what the hawk symbolizes clearly signals the growing pessimism of Yeats's vision: in The Hour-Glass it is seen as an instrument that permits the contemplation of a superior reality, whereas in At the Hawk's Well it is the force, the obstacle that prevents both the Young Man and the Old Man from drinking the waters of the well "of immortality or of wisdom," as Yeats himself referred to it (Saul 49). It is curious to note that Yeats uses similar terms in The Hour-Glass and At the Hawk's Well to describe a "blank" state of the mind: the Wise Man's mind "has been swept bare" (313), just as "the salt sea wind has swept bare" the place dominated by the hawk-woman (208).

If we look at the poem "The Hawk" (1919), we may detect a sense of isolation, however proud, in the hawk's hovering in the clouds. Here the hawk is not seen as an obstacle to anything, but the potentialities the poet declares it may enable in him are but "a pretence of wit," that is, merely fictitious:

Call down the hawk from the air;

Let him be hooded or gaged

Till the yellow eye has grown mild, For larder and spit are bare,

The old cook enraged,

The scullion gone wild.

I will not be clapped in a hood,

Nor a cage, nor alight upon wrist,

Now I have learnt to be proud

Hovering over the wood

In the broken mist

Or tumbling cloud. 
What tumbling cloud did you cleave,

Yellow-eyed hawk of the mind,

Last evening? that $\mathrm{I}$, who had sat

Dumbfounded before a knave,

Should give to my friend

A pretence of wit.

Coming back to the topic of "levels of reality," let us consider At the Hawk's Well. Francisco Javier Torres Ribelles sees the following in this play (80):

In At the Hawk's Well ... there is a "reality" in which the three musicians exist, a deeper one, which is inhabited by the characters themselves, a third one in which the Guardian of the well dances, and it is all, in turn, inside the "reality" entailed by the representation before the audience.

There is also, then, an interplay between different levels of reality in At the Hawk's Well, and we can see how in this respect this play differs technically from the other two, as obviously Yeats does not use shifts between prose and verse in a play, such as this one, which is all written in verse. This signalling function is here carried out by a combination of contrasts between music and absence of it, and also between masks and faces made up to resemble them.

We have already mentioned the growing pessimism of Yeats's vision. This can also be seen if we compare The Shadowy Waters and At the Hawk's Well in the sense that I shall explain now. Consider the ending of The Shadowy Waters: Forgael and Dectora on a voyage at the end of which what they are going to encounter is very probably death. However, this ending cannot be considered pessimistic, as at the same time they are going to find happiness: "happiness abides in the vague destiny of the two main characters" (Torres Ribelles 93). Their souls are going to find immortality in a supreme spiritual communion through which love ultimately triumphs:
Forgael [gathering Dectora's hair about him].
Beloved, having dragged the net about us,
And knitted mesh to mesh, we grow immortal;
And that old harp awakens of itself
To cry aloud to the grey birds, and dreams,
That have had dreams for father, live in us.

The idea of death is identified with that of life here. The deathwish that MacKenzie (84) says eddied in Yeats during the eighties and nineties, when The Shadowy Waters started to take shape, can thus be understood in a positive way. There is, then, a sense of hope in the world-view that this play ultimately proposes. Yeats's perspective changes in the Cuchulain plays. In At the Hawk's Well, on the contrary, neither the Old Man nor Cuchulain are able to drink the waters of immortality. The vision of old age and death in this play changes (208): 
What were his life soon done! Would he lose by that or win?

A mother that saw her son

Doubled over a speckled shin, Cross-grained with ninety years, Would cry, "How little worth Were all my hopes and fears And the hard pain of his birth!"

The Old Man has been trying to drink from the well for fifty years. Yeats, as has often been pointed out, was fifty-one in 1916, when the play was first performed in Lady Cunard's drawing room (Ellmann 215; Kenner 221). Ellmann (216) insists on this possible autobiographical element by asserting that the old man is Yeats's intellect, young Cuchulain is Yeats's instinctive self, and "each is . . . led astray, for neither reason nor instinct had enabled Yeats to drink of the well of wisdom, and each is deluded by the hawk, which symbolizes logic and abstract thought." Cuchulain defies the hawk-woman (216):

Young Man. Why do you fix those eyes of a hawk upon me?

I am not afraid of you, bird, woman, or witch.

[He goes to the side of the well, which the Guardian of the Well has left.]

Do what you will, I shall not leave this place

Till I have grown immortal like yourself.

For all his determination, Cuchulain is deceived by the hawk-woman, as has so often been the case with the Old Man. This cyclical element is explained by Francisco Javier Torres Ribelles, who links it to the idea of negative predestination apparent in Yeats's perspective in this play (93):

In At the Hawk's Well, Yeats sets the two extremes of human existence against each other: on one side the prime of youth, represented by Cuchulain; and opposing it, the decay of old age, embodied in the Old Man. In his early plays the image of the models to imitate was stylised and the tendency to emulation was the manifestation of positive determinism. In At the Hawk's Well, however, a completely different attitude can be perceived. Yeats emphasizes the Old Man's senility while at the same time foregrounding the defects of his contrary. Significantly, these are the defects which have brought the Old Man to his present condition. This is a consolidation of what was beginning to emerge in On Baile's Strand, where the heroic figure's imperfections became visible. The Young Man's repetition of the same mistakes, which reveals the cyclic nature of time and draws him near the other character, increases the sensation of man's helplessness to decide upon his own destiny. Apart from heightening unreality and theatricality, the stage directions of the play, which indicate that the movements of the actors should suggest those of marionettes, distinctly contribute to the construction of an atmosphere of negative predestination. 
In this quasi-Nietzschean repetitiveness there is, then, nothing like the sense of hope that we mentioned apropos of The Shadowy Waters, especially if we think that the level to which the hero Cuchulain is being exalted, in the resulting Yeatsian outlook, cannot compare with that enjoyed by Übermensch Forgael. It is usually said that the Yeatsian vision, in the whole of his production, displays this progressive embitterment. This is often associated with Yeats's difficulty in coming to terms with the process of ageing. I do not question this association, but I would like to emphasize the notion that it is parallelled by the process by which Yeats gradually lets reality-actual, common sense reality-into his vision. Consider The Shadowy Waters: the sailors are portrayed as vulgar, low people with merely material appetites, and the world they symbolize is absolutely despised from the point of view that predominates in the play, which tends to favour Forgael's-and ultimately also Dectora's-world, which symbolizes the world of art and dreams as a means of transcending reality and penetrating the knowledge of the mysteries of life. (Aibric would be a middle term: he is the voice of common sense, but he clearly sympathizes with Forgael and his world.) Reality is rejected, then, and there is an assertion of a dream-world made up of insubstantial elements. Yeats's assertive meaning is very similar in The Hour-Glass, though the negative one is more aptly associable to materialistic science, which is also very close to actual reality, and therefore assimilable in this respect to the world rejected in The Shadowy Waters. At the Hawk's Well is of course, like the whole of Yeats's production, far from being a realistic work, but reality comes in insofar as Yeats here brings into consideration such common sense concerns as youth or old age, however abstracted and emblematized. The consideration is obviously negative in that old age is equated with the repetition of the mistakes of youth. The quest for immortality, viewed so favourably in The Shadowy Waters, is here also seen in a negative light. It seems, anyway, that in At the Hawk's Well Yeats is closer to human realities than ever before, however forlorn his perspective, and however unrealistic his treatment of the subject may be in aesthetic terms. If we look now at Yeats's very last play, The Death of Cuchulain, we may understand the point I am trying to make: in this play reality-not realism, of course-comes in more patently than ever in the sense that Yeats here makes direct references to actual elements of it such as his own empirical, historical self, among others. There is a real sense of desolation in this play. Donoghue (162) thinks that Yeats's relation to his own feeling is turbulent, often self-destructive, he also notes (164-65) that "it is sometimes maintained ... that Yeats is repudiating, once for all, the whole heroic ideal, imagining it in scorn," but his own view is rather that "the Old Man's scorn is visited not upon Cuchulain, Pearse, or Connolly, but upon a world which has let them down." This author also remarks that "by now, the Noh drama has ceased to answer every need; Yeats was no longer willing to hand over every relevant feeling to its determination within the chosen form" (162). I view the adoption of the Noh form in At the Hawk's Well as an affirmative stance on Yeats's part in the sense that I shall explain now: as I see it, the exaltation of the powers of art that is so apparent in The Shadowy Waters is not present in At the Hawk's Well if we think of it in terms of explicit treatment of subject-matter, the object of which, as we suggested earlier, is viewed by Yeats in terms of negation in this latter play. It seems to me that the very act of using a formal aesthetic system which will by itself incorporate into the play the artistic powers that its explicit, 
verbalized thematic content denies, at the same time endows the whole work of art with an element of affirmation of these powers. Yeats's system of values, as far as the affirmative consideration of art is concerned, is in At the Hawk's Well, as it were, not told about, but shown, or performed, as opposed to what happens in The Shadowy Waters, where it is both told about and shown. Following these argumentative lines, I would argue that, for the same reasons, the abandonment of Noh in Yeats's last plays conveys an ingredient of loss, a rejection by Yeats of his earlier aesthetic faith: in The Death of Cuchulain there is nothing affirmative in either form or content. It is perhaps appropriate to reconsider now our last quotation from Donoghue.

If my argument over the last few paragraphs is accepted, particularly the connections between reality and positivity, or affirmation, one cannot help but think that the more Yeats considered reality and the more he let it influence his system of values, the more acrid his general world-view became and the more it became pervaded with a progressive sense of loss of ideals.

Ellmann mentions Yeats's belief that truth was apprehensible by symbols alone and never by direct statement (292). Knowledge and symbolism are thus connected in Yeats's system. In The Hour-Glass, Teigue the fool represents the point of view of a symbolist, while the Wise Man, with all his worthless erudition and his rejection of Teigue's world ("There is nothing but what men can see when they are awake. Nothing, nothing" 306) represents the Lockean-Newtonian world, which Yeats opposed, of absolute science and empiricist confinement of knowledge to measurement of observable matter, and his doubt and death reflect the downfall of this world (Torres Ribelles 35). The Yeatsian truth that Teigue is able to apprehend in The Hour-Glass is in The Shadowy Waters left for the audience to contemplate. The symbolic system in this latter play defies analysis in intellectual terms (De Sola Pinto 84), in a degree higher than it does in The Hour-Glass: it is shadowy and dream-like for the audience, as is for Teigue the knowledge and contemplation of truth.

A feature which all three plays share-together with others by Yeats-in terms of symbolist technique, is the symbolic use of objects. Instances of this are the harp in The Shadowy Waters, the hour-glass and Teigue's flower in The Hour-Glass, and the black cloth with the hawk and the square blue cloth representing the well in At the Hawk's Well. In the latter play, though, it is noticeable that the symbolic objects are further removed from their referents than they are in the other two, in an effort on the part of the author towards incorporeity, stylization, and unreality: in this play we have objects that are symbols of symbols, for instance a cloth which symbolizes a well which in turn symbolizes wisdom or immortality. This procedure goes in the same direction as the use of incorporeal elements such as dance and music with symbolic values. The marionette-like movements of the characters should also be mentioned in this respect. For me, these movements reinforce both the sense of unreality and the symbolism of the ideas of determinism and predestination.

There is a symbol in The Shadowy Waters that is only talked about, and, even though it is repeatedly claimed to be seen hovering above the mast-head by the characters, it is dubious whether it is to be actually seen by the audience. I am obviously referring to the man-headed birds that Forgael claims to be his "only pilots" (150): 
First Sailor. I was sleeping up there by the bulwark, and when I woke in the sound of a harp a change came over my eyes, and I could see very strange things. The dead were floating upon the sea yet, and it seemed as if the life that went out of every one of them had turned to the shape of a man-headed bird-grey they were, and they rose up of a sudden and called out with voices like our own, and flew away singing to the west. Words like this they were singing: "Happiness beyond measure, happiness where the sun dies.”

In so far as they are the souls of the dead, they symbolize the supernatural and parallel the Angel in The Hour-Glass. However, they can be seen in a different sense, symbolizing the artist's inspiration inasmuch as they are the force that drives the artist Forgael, and from which he gets the epistemological force of his art. I think we should view both symbols in conjunction, as Yeats probably wants us to associate art-especially as an instrument for knowledge-with the otherworld of the supernatural. The reversal of death into life which was mentioned earlier should be remembered here too (see 6-7), as the birds drive Forgael towards death, which will bring about the supreme form of knowledge, the ultimate contemplation of truth in immortality.

In terms of character symbolism, I would like to establish a parallel between Forgael and Teigue the fool in the following sense: they both have visionary powers that enable them to have access to knowledge and truth, Teigue through his dreams and Forgael through both his dreams and his art. (MacNeice [74] says there is in The Shadowy Waters a nostalgia for a dream-world which is all knowledge and no action.) They both also have the power of making their visionary faculties available to others: Teigue is willing to share his knowledge with the Wise Man in return for a penny, and, similarly, Forgael's magical harp, symbolizing the epistemological power of art, can charm others into the same contemplation of knowledge that is available to him (149):

Second Sailor: It is said that when he plays upon it he has power over all the listeners, with or without the body, seen or unseen, and any man that listens grows to be as mad as himself.

If we abstract the artistic element, we shall see that both characters are markedly similar in the sense we have just explained.

I see a folk ingredient in Teigue's depiction as a visionary, even though a fool. This folk element is not necessarily Irish, but almost universal, perhaps (it is present in Spanish folk wisdom, anyway), and can be understood by anyone who has noticed the way the "village idiot" is commonly treated in country places: everybody makes fun of him, even to the point of cruelty, but there is also a peculiar sense of respect for him, a curious awareness that he is able to see what most cannot see.

Dectora, who "casts a shadow," contrary to Forgael's hopes and expectations, represents mortal, flesh-and-blood love. (On the other hand, she also embodies the oldfashioned aristocratic values Yeats believed in.) MacNeice (92) thought Yeats was still thinking of Maud Gonne. Forgael's dream of, as MacNeice says in Yeats's own terminology, "a love within the Great Memory-a love on the astral plane," will only 
come true in the timeless experience of the union of both characters in the immortality that they will attain after their death, which they, by severing the rope that links them to the mortal world, voluntarily head for, guided by the birds.

Love-mortal love-is seen in The Shadowy Waters as a source of bitterness: "love is war, and there is hatred in it," says Forgael (162). There are even signs of misogyny. Dectora says (163):

Women are hard and proud and stubborn-hearted, Their heads being turned with praise and flattery; And that is why their lovers are afraid To tell them a plain story.

If Vivian de Sola Pinto is right and "the characters speak with the voice of the poet" (84), this is Yeats speaking through Dectora. The love-hatred equation also appears in At the Hawk's Well. The Old Man is talking to Cuchulain about the hawk-woman's curse (215):

Those that have long to live should fear her most,

The old are cursed already. That curse may be

Never to win a woman's love and keep it;

Or always to mix hatred in the love

In quite different terms, I read the relation between the Wise Man and his wife Bridget in The Hour-Glass as an ironic element aiming at discrediting the Wise Man's values. He, who claims to possess the wisdom of reason, has on the other hand instilled in his docile wife, whom he has thus forced to submit to him, an uncritical blind faith in him. If this is accepted, it would imply quite a feminist, or quasi-feminist stance on Yeats's part, which, nevertheless, does not seem to agree too well with his overall ideology.

Yeats's characters lack psychological depth and are purely emblematic. A symptom of this, in technical terms, can be seen if we look at the stage directions in the plays, where we will find almost no indications of emotional or psychological reactions or tone of the characters', other than those indicating induced states of trance (the only ones I have found are Dectora laughing [162], the Wise Man "speaking with excitement" [306], and the pupils laughing [315 and 316]). What I mean can be more clearly understood if we think of totally different conceptions of drama, such as those we find in the theatre of, say, Eugene O'Neill or Tennessee Williams, where a stage direction may indicate that a given character's gaze, gestures, tone, the way he or she walks, or even his or her clothes, have to make the audience aware of a really complex psychology.

This Yeatsian distaste for the notion of "character" is reflected in extreme terms in At the Hawk's Well, where he makes use of incorporeal symbols such as music and dance, and where the very term "character" even seems almost inappropriate for one like the hawk-woman, who is rather describable as a mere animated symbol (Torres Ribelles 65). Ellmann has the following comment on the symbolic method of At the Hawk's Well, and its relevance in Yeats's dramatic evolution (215): 
Though the play is on Cuchulain, it has no single source in the Cuchulain legends and is purely symbolic, the kind of play Yeats had wanted to create in the nineties but for which he had then lacked method ... Yeats had at last found an adequate medium for his dramatic talents; the collision which we have observed in his earlier dramas between humanity and pattern no longer occurs when the actors wear masks, when they speak a highly specialized language, when a chorus announces that all is set within the mind's eye, and when the climax is a symbolic dance.

It may be a good idea to consider this in relation to what I said earlier about the adoption of Noh as an affirmative stance, and about the negativity implied by its abandonment. It should be borne in mind that $I$ am referring to the importance of this adoption in terms of its significance in the expression of the evolution of Yeats's Weltanschauung, not in terms of the extent to which he could successfully adapt the original Japanese form. In the latter respect, the critic Thomas Parkinson (386) thinks that:

Yeats could not literally adapt Noh form, which is dependent on traditional associations that come from common beliefs shared by writer, actors, and audience and embodied in conventions comprehended in such detail that the most minute gesture is endlessly significant. It seems to me that the "influence" of the Noh on Yeats can easily be exaggerated; the Japanese forms sanctioned and strengthened motives already existent in Yeats's dramaturgy.

The Japanese critic Shotaro Oshima's opinion in his essay on Noh and Kabuki is more appreciative of Yeats's success in adapting Noh: he admits that Noh has "many technical terms unfamiliar to outsiders" (175), but his overall view appears to be that Yeats did manage to capture the spirit or essence of Noh, and he concludes that "we cannot but be impressed at discovering what a profound community of aesthetic sensibility there is between the Irish and the Japanese people" (181).

Symbolist aesthetics is a constant throughout Yeats's theatre. However, in terms of the individual plays, if the main aesthetic referent in At the Hawk's Well is Noh, in The Shadowy Waters it is Pre-Raphaelitism. Eliot thought that this play was "one of the most perfect expressions of the vague enchanted beauty of that school" (252). Apart from the dreamy, misty, fairy-like general atmosphere of the play, other pre-Raphaelite elements include the images of Forgael clutching his harp and Dectora with her crown and her spread hair (which Katharine Worth [16] also relates to Villiers de l'Isle Adam's Axel) the references to insubstantial things, etc. ${ }^{1}$ If the pre-Raphaelite strain is lost in At the Hawk's Well, traces of it still subsist in The Hour-Glass, namely the references to "dreams of angels," and the Angel itself.

The alleged unsuitability of The Shadowy Waters for the stage has been much talked about. Vivian de Sola Pinto says that it is "essentially undramatic" and that Yeats never succeeded in adapting it for the stage (84). As early as 1916, Ernest A. Boyd (155) wrote that:

The latter text [1906] has been retained, but it is condensed and altered in the acting edition, verse and prose being used, instead of blank verse throughout. This modification 
detracts noticeably from the charm of the play, and is a practical admission of its unsuitability to the demands of the theatre. But the beauty of The Shadowy Waters is so essentially poetic, that its qualities as drama are easily forgotten. One reads it, as one reads The Wanderings of Oisin, for the sake of its mood, the elusive mystery of its atmosphere, the delicacy of its expression.

The dramatic claims of the play may be said never to have existed; from the earliest to the latest version the theme remains fundamentally incapable of dramatic expression.

I do not see why the combination of verse and prose should make the play unsuitable for stage performance (Yeats, by the way, would in this case have repeated the mistake in The Hour-Glass) or why the theme should be incapable of dramatic expression. I agree, however, that the strong point of The Shadowy Waters-and even of The Hour-Glass-is not theatrical, but this is far from considering these plays unsuitable for the theatre. I think that the only disadvantages The Shadowy Waters may present for this purpose are certain practical staging difficulties, as reflected, for instance, in the well-known anecdote of the harp that would not blaze to order (Worth 17). It is true, though, that there is a certain undramatic literariness in Yeats's theatre-not just in The Shadowy Waters. I would relate this to the coldness derived from two features already mentioned, namely the lack of psychological depth of the characters, and the absence of explicit indications of tone. The latter trait, in my view, shows that Yeats tried to write plays in which the text would, as it were, speak by itself, that is, be meaningful in its purely literary values. The successful combination of these values with stagecraft had to wait till At the Hawk's Well. The coldness, however, is still there, since it is inherent in Yeats's very outlook, and looks ahead to the well-known epitaph he imagined for himself in his 1938 poem "Under Ben Bulben," which stands on his grave at Drumcliff churchyard. ${ }^{2}$

\section{Notes}

1. Besides the pre-Raphaelite influence, Worth aiso studies Maeterlinckian, Mallarmean, and Wagnerian connections, among others.

2. I am largely indebted to Dr. Brian Hughes for his wise teachings and his invaluable help in the preparation of this paper for the press.

\section{Works Cited}

Bloom, Harold, ed. William Butler Yeats. New York: Chelsea House, 1986.

Bogard, Travis, and William I. Oliver, eds. Modern Drama: Essays in Criticism. New York: Oxford UP, 1965.

Boyd, Ernest A. Ireland's Literary Renaissance. New York: John Lane, 1916.

De Sola Pinto, Vivian. Crisis in English Poetry: 1880-1940. 1967. London: Hutchinson, 1972.

Donoghue, Denis. "Yeats's Theatre." William Butler Yeats. Ed. Harold Bloom. New York:

Chelsea House, 1986. 155-70. 
Eliot, T. S. "Yeats." Selected Prose of T. S. Eliot. Ed. Frank Kermode. London, Faber, 1975. 248-57.

Ellmann, Richard. Yeats: The Man and the Masks. Oxford: Oxford UP, 1979.

Kenner, Hugh. A Colder Eye: The Modern Irish Writers. Harmondsworth: Penguin, 1984.

MacKenzie, Norman H. "Hopkins, Yeats and Dublin in the Eighties." Myth and Reality in Irish Literature. Ed. Joseph Ronsley. Waterloo: Wilfrid Laurier UP, 1977. 77-97.

MacNeice, Louis. The Poetry of W. B. Yeats. London: Faber, 1967.

Oshima, Shotaro. "Between Shapes and Shadows." Myth and Reality in Irish Literature. Ed. Joseph Ronsley. Waterloo: Wilfrid Laurier UP, 1977. 175-81.

Parkinson, Thomas. “The Later Plays of W. B. Yeats." Modern Drama: Essays in Criticism. Ed. Travis Bogard and William I. Oliver. New York: Oxford UP, 1965. 385-93.

Ronsley, Joseph, ed. Myth and Reality in Irish Literature. Waterloo: Wilfrid Laurier UP, 1977.

Saul, G. B. Prolegomena to the Study of Yeats's Plays. Philadelphia: U of Pennsylvania P, 1958.

Torres Ribelles, Francisco Javier. Eternal Shadows: Symbolism in the Theatre of W. B. Yeats. Alicante: Secretariado de Publicaciones de la Universidad de Alicante, 1992.

Worth, Katharine. The Irish Drama of Europe from Yeats to Beckett. 1978. London: The Athlone P, 1986.

Yeats, W. B. The Collected Plays of W. B. Yeats. 1934. London: MacMillan, 1982. . The Collected Poems of W. B. Yeats. 1933. London: MacMillan, 1981. 